demonstrated that a basic dust could best be condition= ed using an acidic conditioner.

\section{RECOMENDATIONS FOR USING GAS CONDITIONING AGENTS}

Before resorting to gas conditioning an electrostatic precipitator it must be established that the problem is due to fly ash resistivity.

High resistivity ashes could best be conditioned using sulphur tri-oxide or other acidic chemicals while pro= blems due to very low resistivity may be more amenable to ammonia.

It is also most essential that gas conditioning of a precipitator 18 not attempted as a "do it yourself job" precipitator 18 not at disaster 18 likely to result. The manufacturers of as disaster 18 have had years of experimentation result = ing in successful application behind them. Inexpert ing in successful applications of conditioning agents can result in, at very best, fallure to be effective and further in corrosion problems, plugging of airheater and precipi= tators and the release of dangerous gases.

\section{REFERENCES}

BGENES, H.0. "Bnhancenent of electrostat1c precipitator performance using flue gas conditioning agents", May 1982 .

EGENES, H.0. "Plue gas conditioning applied to particulate control", January 1983.

DISMUKES, Edward B. "Conditioning of fly ash with sulphur tri-oxide and ammonia", Southern Research Institute. August 1975.

\title{
THE CAPE POINT TRACE GAS MONITORING PROGRAMME
}

\section{E G BRUNKE}

World-wlde concern about the possible enviromental influences of certain atmospherlc trace gases gave rise to the International Conference in Stockholm in 1976, where a call went out to nations to participate in a Global Environmental Monitoring system. In 1977 Dr Halliday took the initiative on behalf of the CSIR and established a small baseline station at Cape Point, which satisfies the essential requirements for the background monitoring of the trace gases. During most of the time, measurements are made in air derived from the South Atlantic.

The analytical instruments are housed in a little building kindly rented to the CSIR by the Department of Transport, whose light-house generator also supplies the electricity. After a very modest beginning with the occasional air sample being collected and mailed to Pretoria for analysis, the project has grown consi= derably over the past five years mainly with the assistance obtained from the Max Planck Institute in West Germany. The Cape Point team now comprises two researchers, one technician and a data processor, who have office, laboratory and computer facilities at the have of Accelerator Centre/Paure. At present $\mathrm{CO}$ and $\mathrm{O}_{3}$ are being measured continuously and $\mathrm{F}-11, \mathrm{CCl}_{4}, \mathrm{CH}_{4}$ and $\mathrm{N}_{2} \mathrm{O}$ on a semi-continuous basis. In addition, an and $\mathrm{N}_{2} \mathrm{O}$ on a semi-continuous basis. records wind velocities and automatic anemometer records Meteorological parameters dich as temperature and pressure are obtained from the such as temperature and prose collect these data for the Weather Bureau. The hourly averages of the 11 para= meters measured, comprises 77745 data points per year, which are handled by the CSIR's computer in Pretoria.

The enviromental importance of the $s 1 x$ trace gases being monitored can be divided into two caregories:

* those which directly or indirectly attack the stratospheric ozone layer; the earth's UV filter

* those which absorb IR radiation, thereby contri= buting to the 'greenhouse effect'.

The co measurements made in Cape Point since 1978, represent the longest and only continuous $C O$ record in the Southern Hemisphere. The main interest in $\mathrm{CO}$, is that its dominant link is the reaction with hydroxyl that its dominant link 18 the reaction pollutants including 'greenhouse' and ' $\mathrm{O}_{3}$-destroying' gases.

In the Northern Hemisphere fossil fuel use is believed to be responsible for $23 \%$ of the total co source strength. The ambient CO level at Cape Point displays a repetitive annual cycle with a spring high ( $82 \mathrm{ppbV})$ and summer low ( $53 \mathrm{ppbV})$. Various arguments suggest and summer low seasonal variation 18 a function of the annual ITCZ shift. As a consequence, it is impossible at this stage to say whether the Co level is rising or not.

Atmospheric $\mathrm{CH}_{4}$, which has a mean troposhperic mixing ratio of $1,6 \mathrm{ppmV}$, has in recent years aroused consi= derable interest, because it is considered to be the $\mathrm{CH}$ is also an important remover of $\mathrm{OH}$ during which 18 generated. Methane is produced in swamps and rice fields and by the digestive processes in cattle and termites. These processes are largely coupled to the world's increasing food production and as such it is not surprising that scientists elsewhere around the globe have observed a $\mathrm{CH}_{4}$ increase ranging between 1 and $2 \%$ annually. As our data base at Cape Point is only 1,5 years old, no such inferences can yet be made.

The tropospheric $\mathrm{O}_{3}$ cycle must be viewed in conjunction with those of $\mathrm{CO}, \mathrm{CH}_{4}$ and $\mathrm{OH}$. Ozone, which is a small IR absorber, does not solely originate from the strato= sphere as has previously been assumed, but is also produced in the unpolluted troposphere. Together with sunlight and water vapour it forms the mafor source of tropospheric OH. Amblent $\mathrm{O}_{3}$ concentrations have been monitored at Cape Point since 1979, but unlike CO, no repetitive annual cycle has been observed. During the years 1979 and 1981, however, a spring high was re corded, which is belleved to be the result of strato= corded, which is belleved to be the the $1982 \mathrm{O}_{3}$ mean (21 $t+$ ppbV) compares favourably with those annual means reported by other global baseline stations such as the one in Tasmania (23 ppbV) and the one at the South Pole (20 ppbV).

Freon-11 is a man-made gas which is mainly used in aerosol cans. When $\mathrm{F}-11$ reaches the stratosphere $1 \mathrm{t}$ is photolyzed, whereby $0_{3}$-destroying $\mathrm{Cl}$ atoms are liberated. Additionally, F-11 also absorbs some IR radiation. Carbon tetrachloride, which probably has both natural as well as anthropogenic sources is, like $\mathrm{F}-11$, a potential destroyer of stratosphere $\mathrm{O}_{3}$.

The halocarbon means for the first five months of 1983 The annual were: $\mathrm{F}-11$ rate of $\mathrm{F}-11(1979-1980)$ was $11,8 \mathrm{pptV}$, but gas since come down to $8,6 \mathrm{pptV}$. This decline in the atmospheric accumulation rate of $\mathrm{F}-11$ is to be expected 
after several countries, notably the USA, had placed a ban on the essential uses of F-11 and F-12. Nonethe= less, F-11 is still increasing in the atmosphere and a vigilant check on its growth has to be maintained. Carbon tetrachloride has shown a small, but steady rise $\left(3,7 \mathrm{pptV} /\right.$ year $\left.^{-1}\right)$ since 1980 , which agrees well with estimates made in other parts of the world.

Nitrous oxide is, like F-11, relatively inert in the troposhere, whilst in the stratosphere it reacts with excited oxygen atoms to yield nitric oxide, whtch plays a pivotal role in $\mathrm{O}_{3}$-destroying reactions. Micorbial activity in anaerobic soils and ocean sediments produce $\mathrm{N}_{2} \mathrm{O}$. The strength of this source is magnified by the world-wide use of $\mathrm{N}$-fertilizers. Measurements of $\mathrm{N}_{2} \mathrm{O}$ were inftiated at Cape Point in March this year. To date little monthly changes have been detected (average : $295 \mathrm{ppbV}$ ).

The basic project of monttoring gases, which absorb IR radiation or which influence stratospheric chemistry, will continue at Cape Point. Additionally, it is planned to expand the measuring programme to include such parameters as solar flux, $\mathrm{HCNO}, \mathrm{NO}_{\mathrm{x}}$ and $\mathrm{H}_{2}$, in order to obtain a better understanding of the chemical cycle involving $\mathrm{CH}_{4}$, $\mathrm{OH}$ and $\mathrm{CO}$.

In air-chemical research circles, a general need exists to verify and quantify theoretical models of trace gas cycles by good-quality in situ measurements. In this way the abilfty of the atmosphere to absorb and neutrallze man-made pollutants can best be checked.

With the technical ground work already being laid and its favourable geographic position in the South Atlantic Ocean, Cape Point is ideally suited for such a study.

B G Brunke Atmospheric Sclences Division National Physical Research Laboratory CSIR

August 1983

\section{LONG-TERM TRENDS IN SMOKE AND SULPHUR DIOXIDE}

\section{POLLUTION IN SOUTH AFRICA}

DR E KEMENY \& C M VLEGGAAR

ATMOSPHERIC SCIENCES DIVISION

NATIONAL PHYSICAL RESEARCH LABORATORY

At present 33 cities and towns participate in the national survey on smoke and sulphur dioxide and in a recently 1ssued report (1) the results obtained between October 1980 and September 1982 were statistically ana= lysed together with those collected in previous years. This report reveals the alarming fact that the concen = trations of smoke and sulphur dioxide no longer have the tendency to decrease as was the case up to 1978.
Instead, between 1978 and 1982 the concentrations of smoke fluctuated without showing any tendency at $95 \%$ of the 112 monitoring 81 tes and the $\mathrm{SO}_{2}$ concentrations did likewise at $81 \%$ of the 64 measuring sites. As far as the tendency to increase is concerned, $1 \%$ of the smoke and $13 \%$ of the $\mathrm{SO}_{2}$ stations have this tendency, which for $\mathrm{SO}_{2}$ represents an increase of $4 \%$ in comparison with the past.

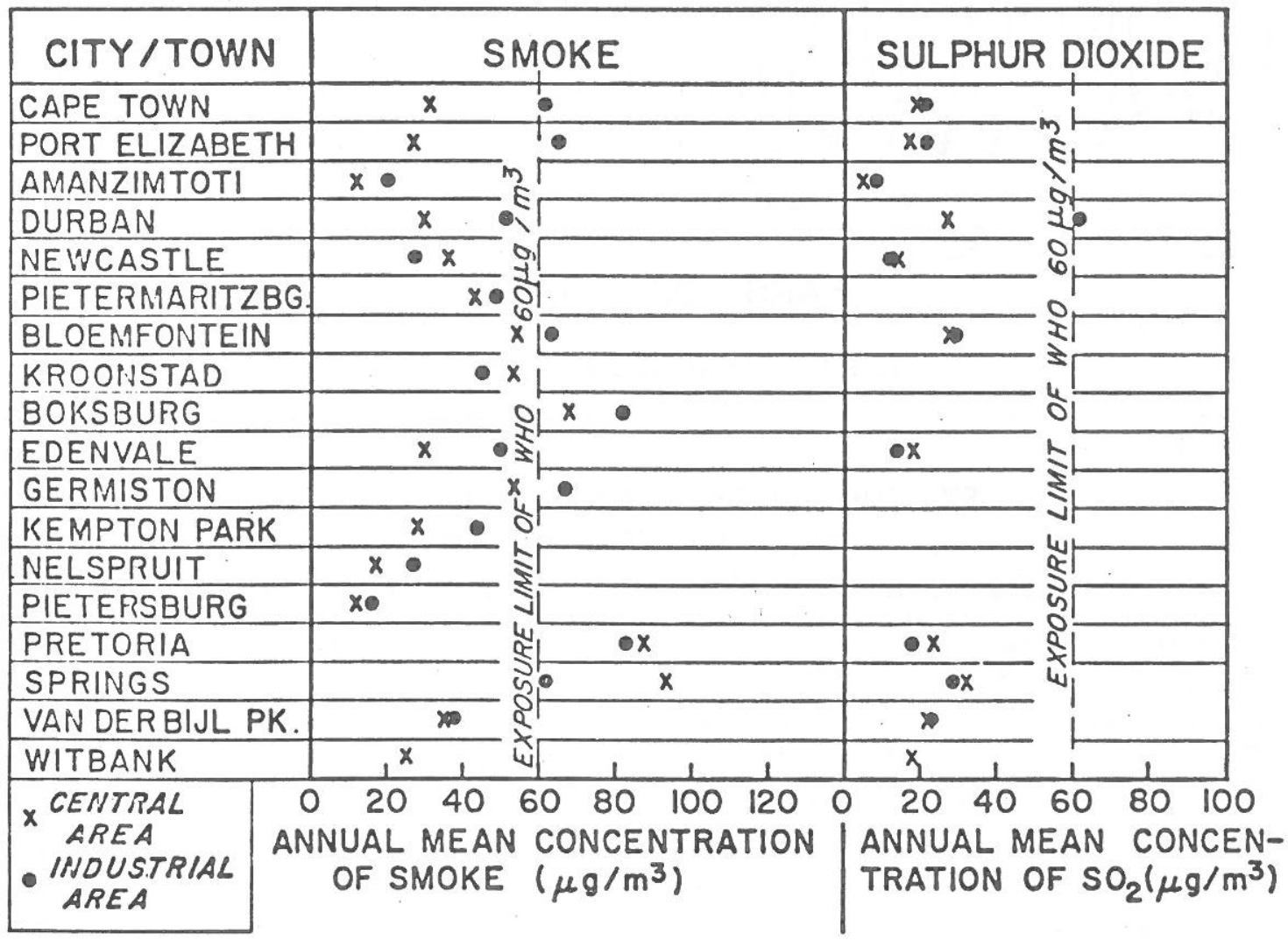

FIGURE 1 SOUTH AFRICAN SMOKE AND SULPHUR DIOXIDE LEVELS IN RELATION TO EXPOSURE LIMITS OF WORLD HEALTH ORGANIZATION 